\title{
PEMANFAATAN TEPUNG AMPAS KELAPA DALAM PEMBUATAN FLAKES CEREAL (KAJIAN PROPORSI TEPUNG AMPAS KELAPA: TEPUNG BERAS)
}

\author{
Utilization of Coconut Dregs Flour in Cereal Flakes Production \\ (Study of Coconut Dregs Flour: Rice Flour Proportion)
}

\author{
Nurrahmah Fitra Sabilla, Erni Sofia Murtini* \\ Jurusan Teknologi Hasil Pertanian - Fakultas Teknologi Pertanian - Universitas Brawijaya \\ Jl. Veteran - Malang 65145 \\ *Penulis Korespondensi, email: erni.murtini@ub.ac.id
}

Disubmit: 3 Juli 2020 Direvisi: 11 Agustus 2020 Diterima: 5 Desember 2020

\begin{abstract}
ABSTRAK
Ampas kelapa merupakan hasil samping pengolahan santan kelapa yang pemanfaatannya masih terbatas. Nilai nutrisi ampas kelapa yang cukup baik membuatnya berpotensi untuk diolah menjadi produk pangan sarapan, yaitu flakes cereal. Ampas kelapa yang digunakan dapat meningkatkan kandungan serat flakes. Penggunaan tepung ampas kelapa dalam pembuatan flakes dikombinasikan dengan tepung beras putih. Penelitian bertujuan untuk mengetahui proporsi penggunaan tepung ampas kelapa:tepung beras yang tepat dalam pembuatan flakes dan pengaruhnya terhadap daya patah, tingkat rehidrasi dalam media saji, kadar air, kadar serat kasar, kadar protein, dan kadar lemak, serta untuk mendapatkan perlakuan terbaik dari parameter tersebut. Penelitian menggunakan desain Rancangan Acak Kelompok (RAK) satu faktor perlakuan berupa proporsi penggunaan tepung ampas kelapa:tepung beras yang terdiri dari 6 level (80:20, 70:30, 60:40, 50:50, 40:60, 30:70) dengan 5 kali pengulangan. Data yang didapatkan dianalisa dengan ANOVA dan dilanjutkan dengan uji lanjut BNT dengan selang kepercayaan 95\%. Flakes perlakuan terbaik berdasarkan karakteristik fisik dan kimia ditentukan dengan metode Multiple Attribute Decision Making. Perhitungan nilai AKG dilakukan terhadap flakes perlakuan terbaik. Flakes perlakuan terbaik terbuat dari 80\% tepung ampas kelapa dan 20\% tepung beras, memiliki nilai daya patah sebesar $0,14 \pm 0,05 \mathrm{~N}$, tingkat rehidrasi dalam media saji sebesar $61,67 \pm 0,98 \%$, kadar air sebesar 3,4 $\pm 0,26 \%$, kadar serat kasar sebesar $12,12 \pm 0,78 \%$, kadar protein

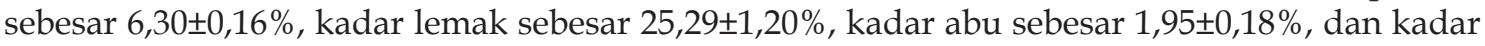
karbohidrat sebesar $63,06 \pm 1,11 \%$. Nilai AKG flakes perlakuan terbaik dalam satu takaran saji (30 g) adalah $11 \%$ lemak total, $3 \%$ protein, $6 \%$ karbohidrat total, $12 \%$ serat pangan tak larut, dengan nilai energi total sebesar $150 \mathrm{Kkal}$
\end{abstract}

Kata kunci : Flakes Cereal; Proporsi Tepung; Tepung Ampas Kelapa; Tepung Beras

\begin{abstract}
Coconut dregs is a byproduct of coconut milk processing and its use is still limited. The good nutritional value of coconut dregs makes it potential to be processed into breakfast food, specifically cereal flakes. Coconut dregs can increase the fiber content of flakes. The use of coconut dregs flour combined with white rice flour. The objective of this research was to find the right proportion of coconut dregs flour:rice flour in producing cereal flakes and their effect on fracturability, rehydration, moisture content, crude fiber content, protein content, and fat content of flakes, also to obtain the best treatment of those parameters. This research used Randomized Block Design with 1 factor, the proportion of coconut dregs flour:rice flour in 6 differents level (80:20, 70:30, 60:40, 50:50, 40:60, 30:70) with 5 replications. The data were subjected to analysis of variance (ANOVA) and further tested by LSD test with 95\% confidence interval. The best treatment results based on the physical and chemical characteristic of flakes
\end{abstract}


was obtained by Multiple Attribute Decision Making method. The Recommended Dietary Allowance $(\% R D A)$ was calculated to the best treatment flakes. The best treatment was found in the flakes made with the proportion of $80 \%$ coconut dregs flour and $20 \%$ rice flour. The best flakes have the characteristics of $0,14 \pm 0,05 N$ fracturability, $61,67 \pm 0,98 \%$ rehydration, $3,4 \pm 0,26 \%$ water content, $12,12 \pm 0,78 \%$ crude fiber content, $6,30 \pm 0,16 \%$ protein content, $25,29 \pm 1,20 \%$ fat content, $1,95 \pm 0,18 \%$ ash content, and $63,06 \pm 1,11 \%$ carbohydrate content. The $\%$ RDA of the best treatment flakes in one serving size (30 g) are $11 \%$ total fat, $3 \%$ protein, $6 \%$ total carbohydrate, $12 \%$ insoluble dietary fiber, and $150 \mathrm{kcal}$ total energy

Keywords : Cereal Flakes, Coconut Dregs Flour, Flour Proportion, Rice Flour

\section{PENDAHULUAN}

Proses pengolahan santan akan menghasilkan limbah berupa ampas kelapa. Menurut FAOSTAT (2020) Indonesia adalah penghasil kelapa terbesar nomer satu di dunia dengan produksi pada tahun 2018 sebesar 18555000 ton. Jika rata-rata berat daging buah kelapa adalah $28 \%$, maka angka tersebut setara dengan 5 juta ton daging buah kelapa. Jika semua daging buah kelapa tersebut digunakan untuk memproduksi santan, dan jika dalam pembuatan santan dihasilkan 40\% ampas, maka akan dihasilkan sekitar 2 juta ton ampas kelapa, sehingga ketersediaan ampas kelapa sangat melimpah.

Menurut Hafiza et al. (2012), ampas kelapa tersusun atas 56,5\% karbohidrat, 24,1\% serat kasar, 7,3\% air, 3,5\% protein, 2,2\% abu, dan memiliki kalori sebesar 515 Kkal dalam $100 \mathrm{~g}$ ampas kelapa. Meskipun memiliki nilai nutrisi yang baik, hingga saat ini pemanfaatan ampas kelapa dalam bidang pangan masih terbatas karena ampas kelapa cukup rentan terhadap kerusakan. Kerusakan berupa terjadinya ketengikan pada ampas kelapa jika tidak segera diolah dan dibiarkan terlalu lama. Aplikasi teknologi penepungan pada ampas kelapa akan meningkatkan umur simpannya. Peningkatan umur simpan ini terjadi karena proses penepungan akan menurunkan kadar air pada ampas kelapa. Selain itu, ampas kelapa dalam bentuk tepung juga lebih mudah untuk diformulasikan menjadi sebuah produk pangan. Kadar serat yang tinggi membuat tepung ampas kelapa berpotensi untuk diolah menjadi produk pangan sarapan. Menurut Fife (2014), mengonsumsi makanan tinggi serat pada saat sarapan akan memberikan efek kenyang yang lebih lama. Hal ini disebabkan karena makanan dengan kadar serat tinggi membutuhkan waktu cerna yang lebih panjang.
Salah satu produk alternatif sarapan yang dapat dibuat dengan memanfaatkan tepung ampas kelapa adalah flakes. Flake merupakan salah satu jenis breakfast cereals yang berbentuk pipih, dan umumnya terbuat dari biji-bijian seperti gandum, jagung, dan beras. Flakes merupakan produk pangan yang dapat langsung dikonsumsi, baik dengan maupun tanpa penambahan susu sehingga produk ini banyak dipilih sebagai menu sarapan (Bhattacharya, 2015). Karakteristik flakes yang dihasilkan sangat dipengaruhi oleh jenis bahan baku yang digunakan. Bahan baku dengan kandungan pati yang tinggi akan menghasilkan flakes dengan tekstur yang lebih renyah (Maskan, 2012). Rendahnya kadar pati pada tepung ampas kelapa membuat dibutuhkannya bahan lain sebagai sumber pati agar dihasilkan flakes dengan tekstur yang lebih baik. Bahan dasar dan sumber pati yang umum digunakan pada produk flakes adalah tepung terigu. Namun, adanya kandungan gluten pada tepung terigu membuat produk pangan yang terbuat dari tepung terigu tidak bisa dikonsumsi oleh penderita penyakit celiac, karena meski dalam jumlah yang sangat kecil gluten dapat menyebabkan inflamasi pada usus halus dan malabsorpsi beberapa nutrisi penting seperi zat besi, asam folat, dan vitamin larut lemak (Hosseini et al., 2018). Berdasarkan hal tersebut, pada penelitian ini penggunaan tepung ampas kelapa pada pembuatan flakes akan dikombinasikan dengan tepung beras putih. Menurut Immaningsih (2012), kadar pati yang dimiliki tepung beras juga cukup tinggi yaitu mencapai $67,68 \%$ sehingga diharapkan kombinasi antara tepung ampas kelapa dan tepung beras dapat menghasilkan tekstur flakes yang baik.

Penelitian ini bertujuan untuk mengetahui pengaruh perbedaan proporsi penggunaan tepung ampas kelapa:tepung beras 
terhadap sifat fisik dan kimia flakes yang dihasilkan, serta untuk mendapatkan flakes dengan karakteristik terbaik. Penyusunan informasi nilai gizi dan angka kecukupan gizi dilakukan pada flakes perlakuan terbaik.

\section{METODE}

Bahan yang digunakan dalam pembuatan produk antara lain kelapa parut yang diperoleh dari Pasar Dinoyo Malang, tepung beras putih (Rose Brand), telur, gula halus (Cap Semut), garam meja (Refina), susu skim yang diperoleh dari Toko Prima Rasa Malang, dan air. Bahan yang digunakan untuk analisa antara lain etanol, $\mathrm{PE}, \mathrm{NaOH}$, aquades, $\mathrm{H}_{2} \mathrm{SO}_{4^{\prime}}, \mathrm{K}_{2} \mathrm{SO}_{4} 10 \%, \mathrm{H}_{3} \mathrm{BO}_{3} 3 \%$, kertas saring, $\mathrm{HCl} 0,1 \mathrm{~N}$, indikator $\mathrm{PP}$, indikator metil merah, kapas, dan benang kasur. Bahan yang digunakan sebagai produk pembanding adalah Corn Flakes (Nestle) sebagai flakes komersial 1 dan Instant Oatmeal (Quaker) sebagai flakes komersial 2.

Alat yang digunakan dalam pembuatan produk antara lain pengering kabinet otomatis, pemarut kelapa, blender (Kirin), ayakan 60 mesh, oven listrik (Kirin), mixer (Philips), kompor, timbangan digital (CHQ), termometer, pasta maker, pengukus, pisau, baking paper, dan loyang. Alat yang digunakan untuk analisa antara lain glassware, timbangan analitik (CHQ), oven listrik, desikator, refluks, lemari asam, labu lemak, cawan porselen, furnace, corong, pengangas air, texture analyzer, dan distiller.

Penelitian ini menggunakan Rancangan Acak Kelompok (RAK) dengan satu faktor perlakuan berupa proporsi penggunaan tepung ampas kelapa:tepung beras (\%:\%) yang terdiri dari 6 level yaitu yaitu 80:20, 70:30, 60:40, 50:50, 40:60, 30:70 dengan 5 kali pengulangan sehingga didapatkan 30 satuan percobaan.

\section{Pembuatan Tepung Ampas Kelapa}

Daging buah kelapa yang telah dikupas lapisan kulit luarnya diparut menggunakan mesin pemarut kelapa, lalu dihilangkan santannya dengan cara diperas menggunakan kain saring. Selanjutnya, ditambahkan air dengan perbandingan 1:1 (b/v), didiamkan selama 5 menit, dan diperas kembali. Selanjutnya dilakukan perebusan ampas kelapa pada suhu $100{ }^{\circ} \mathrm{C}$ selama 5 menit dengan perbandingan kelapa: air 1:2 (b/v). Ampas kelapa kemudian dikeringkan dengan pengering kabinet pada suhu $60^{\circ} \mathrm{C}$ selama 5 jam, dihancurkan menggunakan blender, dan diayak menggunakan ayakan 60 mesh.

\section{Pembuatan Flakes}

Langkah pertama yang dilakukan adalah menimbang bahan-bahan, yaitu telur 20\% (b/b tepung), gula halus $18 \%$ (b/b tepung), susu skim $6 \%$ (b/b tepung), garam $1 \%(b / b$ tepung), air $80 \%$ ( $\mathrm{b} / \mathrm{b}$ tepung), serta tepung ampas kelapa:tepung beras sesuai dengan proporsi. Selanjutnya, seluruh bahan-bahan dicampurkan dan dilakukan pengadukan menggunakan mixer pada kecepatan 1 selama 3 menit. Adonan sebanyak $100 \mathrm{~g}$ dimasukkan ke dalam loyang berukuran 7x18 cm dan dikukus selama 5 menit. Suhu pengukusan dikontrol menggunakan termometer pada suhu $70^{\circ} \mathrm{C}$. Setelah itu, adonan didiamkan selama 5 menit pada suhu ruang, kemudian adonan dipipihkan menggunakan pasta maker hingga ketebalan $2 \mathrm{~mm}$ dan dicetak menggunakan cookie cutter dengan ukuran $2 \times 2 \mathrm{~cm}$. Flakes kemudian dipanggang dengan oven pada suhu $200{ }^{\circ} \mathrm{C}$ selama 7 menit.

\section{Parameter Pengamatan}

Bahan baku tepung ampas kelapa akan dianalisa kadar air metode oven (AOAC, 1990), kadar serat kasar (AOAC, 1995), kadar lemak (SNI 01-2891-1992), kadar protein (AOAC, 2005), kadar abu (SNI 01-28911992), dan kadar karbohidrat (AOAC, 2000). Produk flakes akan dianalisa fisik dan analisa kimia. Analisa fisik berupa analisa daya patah menggunakan Texture Analyzer (Yuwono dan Susanto, 1998), dan tingkat rehidrasi dalam media saji susu (Ranganna, 1977), analisa kimia berupa kadar air metode oven (AOAC, 1990), kadar serat kasar (AOAC, 1995), kadar lemak (SNI 01-2891-1992), dan kadar protein (AOAC, 2005).

\section{Analisis Data}

Data dianalisa ragam (Analysis of Variance) menggunakan aplikasi Minitab 17 dengan selang kepercayaan 95\% untuk mengetahui pengaruh perlakuan terhadap variabel yang diukur. Uji lanjut akan dilakukan dengan metode uji BNT (Beda Nyata Terkecil) dengan selang kepercayaan 95\%. Analisa korelasi dengan metode Pearson Correlation digunakan untuk mengetahui hubungan antara dua variabel. Flakes dengan perlakuan terbaik dari parameter fisik dan kimia akan 
ditentukan menggunakan metode Multiple Attribute Decision Making. Parameter fisik flakes perlakuan terbaik ditentukan berdasarkan preferensi subjektif, sedangkan kriteria parameter kimia ditentukan dengan mengacu pada SNI 2973:2011. Nilai gizi flakes perlakuan terbaik akan dibandingkan dengan dua produk flakes komersial.

\section{HASIL DAN PEMBAHASAN}

Analisa bahan baku tepung ampas kelapa dilakukan agar diketahui kondisi awal kondisi awal dari bahan baku yang digunakan sebelum diolah menjadi flakes. Analisa bahan baku yang dilakukan meliputi analisis kadar air, kadar protein, kadar lemak, kadar serat kasar, kadar abu, dan kadar karbohidrat by difference (Tabel 1).

Tepung ampas kelapa memiliki kadar serat kasar yang cukup tinggi yaitu sebesar 17,74 $\pm 0,79 \%$. Menurut Galanakis (2019), penggunaan tepung tinggi serat dalam jumlah dan ukuran partikel tertentu akan mempengaruhi karakteristik akhir dari suatu produk pangan. Pada produk flakes, penggunaan bahan baku yang mengandung serat larut air (Soluble Dietary Fiber) akan menghasilkan tekstur yang lebih liat, sedangkan komponen serat tak larut (Insoluble Dietary Fiber) akan menghasilkan flakes dengan karakteristik yang lebih rapuh.

Komponen lain pada tepung ampas kelapa yang cukup tinggi adalah lemak, yaitu sebesar 34,42 $\pm 0,92 \%$. Menurut Ramaswamy (2014), proses ekstraksi yang melibatkan air pada metode ini tidak efektif untuk menghilangkan lemak sehingga kadar lemak yang tertinggal masih cukup tinggi. Menurut
Zhu et al. (2014), kandungan lemak ini akan berpengaruh terhadap aroma yang dihasilkan.

Tepung ampas kelapa memiliki kandungan protein yang cukup rendah yaitu sebesar 3,75 $\pm 0,13 \%$. Menurut Provost et al. (2016), protein dapat mempengaruhi karakteristik flakes karena protein dapat terdenaturasi dalam proses pemanggangan. Kandungan protein yang rendah akan menghasilkan tekstur yang lebih rapuh.

Bahan baku utama selain tepung ampas kelapa adalah tepung beras. Tepung beras memiliki kandungan pati yang cukup tinggi, yaitu $67,68 \%$. Adanya pati dapat mempengaruhi karakteristik akhir suatu produk pangan karena pati dapat mengalami perubahan selama proses pengolahan. Pada proses pengukusan, adanya uap panas yang dihasilkan dari air yang mendidih serta kehadiran molekul air di dalam adonan flakes menyebabkan terjadinya proses pra-gelatinisasi pati. Pada tahap ini, air akan masuk ke dalam granula pati sehingga terjadi pembengkakan granula. Pada proses pemanggangan, terjadi penguapan air yang membuat terbentuknya rongga-rongga pada granula pati. Hal ini akan menghasilkan tekstur renyah pada flakes (Zhou, 2014). Penggunaan tepung yang mengandung pati dalam jumlah yang tepat juga dapat meningkatkan kerenyahan flakes (BeMiller, 2009).

\section{Karakteristik Kimia Flakes}

Karakteristik kimia flakes yang meliputi kadar serat kasar, kadar air, kadar protein, dan kadar lemak dapat dilihat pada Tabel 2.

\section{Kadar Serat Kasar}

Kadar serat kasar flakes berkisar antara 4,44-12,12\%. Perbedaan proporsi tepung ampas kelapa dan tepung beras memberikan

Tabel 1. Hasil analisa bahan baku

\begin{tabular}{lccc}
\hline \multirow{2}{*}{ Parameter } & \multicolumn{2}{c}{ Tepung Ampas Kelapa } & Tepung Beras Putih \\
\cline { 2 - 4 } & Hasil Analisa & Literatur & USDA $^{\mathrm{a}}$ \\
\hline Kadar Air (\%) & $4,57 \pm 0,32$ & $2,5 \pm 0,3$ & 11,89 \\
\hline Kadar Protein (\%) & $3,75 \pm 0,13$ & $4,2 \pm 0,2$ & 5,95 \\
\hline Kadar Lemak (\%) & $34,42 \pm 0,92$ & $42,6 \pm 1,2$ & 1,42 \\
\hline Kadar Serat Kasar (\%) & $17,74 \pm 0,79$ & $23,2 \pm 0,8$ & - \\
\hline Kadar Abu $(\%)$ & $0,48 \pm 0,14$ & $1,2+0,8$ & 0,61 \\
\hline Pati $(\%)$ & - & - & $67,68^{c}$ \\
\hline Karbohidrat $(\%)$ & $56,55 \pm 1,02$ & $19,2 \pm 3,2$ & 80,13 \\
\hline
\end{tabular}

Keterangan: data yang ditampilkan adalah rerata dari 5 kali ulangan \pm standar deviasi; a. Yalegama (2013); b. USDA (2019); c. Immaningsih (2012) 
pengaruh nyata $(\alpha=0,05)$ terhadap kadar serat kasar flakes. Kadar serat kasar flakes cenderung menurun seiring dengan berkurangnya proporsi tepung ampas kelapa dan bertambahnya proporsi tepung beras yang digunakan. Penurunan kadar serat kasar flakes seiring dengan berkurangnya proporsi tepung ampas kelapa dan bertambahnya proporsi tepung beras disebabkan karena kadar serat kasar pada tepung ampas kelapa lebih tinggi dibandingkan dengan tepung beras, dimana kadar serat kasar tepung ampas kelapa sebesar 17,74 $\pm 0,79 \%$ dan kadar serat kasar tepung beras sebesar 0,60 $\pm 0.23 \%$ (Sereewat, 2015). Hal ini menunjukkan bahwa kandungan serat kasar pada tepung ampas kelapa 29 kali lebih tinggi dibandingkan dengan tepung beras. Oleh karena itu, penurunan proporsi tepung ampas kelapa menyebabkan penurunan kadar serat kasar flakes yang signifikan. Kadar Air

Kadar air flakes berkisar antara 1,23\% hingga 3,40\%. Perbedaan proporsi tepung ampas kelapa dan tepung beras memberi- kan pengaruh nyata $(\alpha=0,05)$ terhadap kadar air flakes. Kadar air flakes cenderung menurun seiring dengan berkurangnya proporsi tepung ampas kelapa dan bertambahnya proporsi tepung beras yang digunakan. Penurunan kadar air flakes seiring dengan berkurangnya proporsi tepung ampas kelapa dan bertambahnya proporsi tepung beras disebabkan karena adanya perbedaan karakteristik dari bahan baku utama yang digunakan. Sebagian besar komponen penyusun tepung ampas kelapa adalah serat, sedangkan tepung beras memiliki serat yang jauh lebih rendah dibandingkan dengan tepung ampas kelapa. Adanya hubungan antara kadar air dan kadar serat kasar flakes dapat dilihat pada Gambar 1. Kadar serat kasar flakes menentukan kadar air flakes sebesar 87,09\%. Uji korelasi Pearson menghasilkan nilai signifikansi sebesar 0,000 dengan koefisien korelasi sebesar 0,933 yang menunjukkan adanya korelasi yang tinggi antara kadar air dengan kadar serat kasar flakes dengan nilai positif dimana semakin tinggi kadar

Tabel 2. Rerata kadar serat kasar, kadar air, kadar protein, dan kadar lemak flakes

\begin{tabular}{ccccc}
\hline $\begin{array}{c}\text { Proporsi Tepung Ampas Kelapa: } \\
\text { Tepung Beras (\%:\%) }\end{array}$ & $\begin{array}{c}\text { Kadar Serat } \\
\text { Kasar }(\%)\end{array}$ & $\begin{array}{c}\text { Kadar Air } \\
(\%)\end{array}$ & $\begin{array}{c}\text { Kadar Protein } \\
(\%)\end{array}$ & $\begin{array}{c}\text { Kadar } \\
\text { Lemak }(\%)\end{array}$ \\
\hline $80: 20$ & $12,12 \pm 0,78^{\mathrm{a}}$ & $3,40 \pm 0,26^{\mathrm{a}}$ & $6,30 \pm 0,16^{\mathrm{f}}$ & $25,29 \pm 1,20^{\mathrm{a}}$ \\
\hline $70: 30$ & $10,55 \pm 0,38^{\mathrm{b}}$ & $2,57 \pm 0,15^{\mathrm{b}}$ & $6,46 \pm 0,21^{\mathrm{e}}$ & $21,81 \pm 1,65^{\mathrm{b}}$ \\
\hline $60: 40$ & $8,55 \pm 0,62^{\mathrm{c}}$ & $2,26 \pm 0,14^{\mathrm{c}}$ & $6,70 \pm 0,30^{\mathrm{d}}$ & $19,39 \pm 1,20^{\mathrm{c}}$ \\
\hline $50: 50$ & $6,99 \pm 0,60^{\mathrm{d}}$ & $1,98 \pm 0,19^{\mathrm{d}}$ & $6,95 \pm 0,27^{\mathrm{c}}$ & $18,10 \pm 0,89^{\mathrm{d}}$ \\
\hline $40: 60$ & $5,62 \pm 0,52^{\mathrm{e}}$ & $1,64 \pm 0,26^{\mathrm{e}}$ & $7,17 \pm 0,29^{\mathrm{b}}$ & $17,23 \pm 0,35^{\mathrm{e}}$ \\
\hline $30: 70$ & $4,44 \pm 0,63^{\mathrm{f}}$ & $1,23 \pm 0,27^{\mathrm{f}}$ & $7,37 \pm 0,22^{\mathrm{a}}$ & $12,60 \pm 0,85^{\mathrm{f}}$ \\
\hline
\end{tabular}

Keterangan: data yang ditampilkan adalah rerata dari 5 kali ulangan \pm standar deviasi; angka yang di dampingi notasi berbeda menunjukkan perbedaan nyata $(a=0,05)$

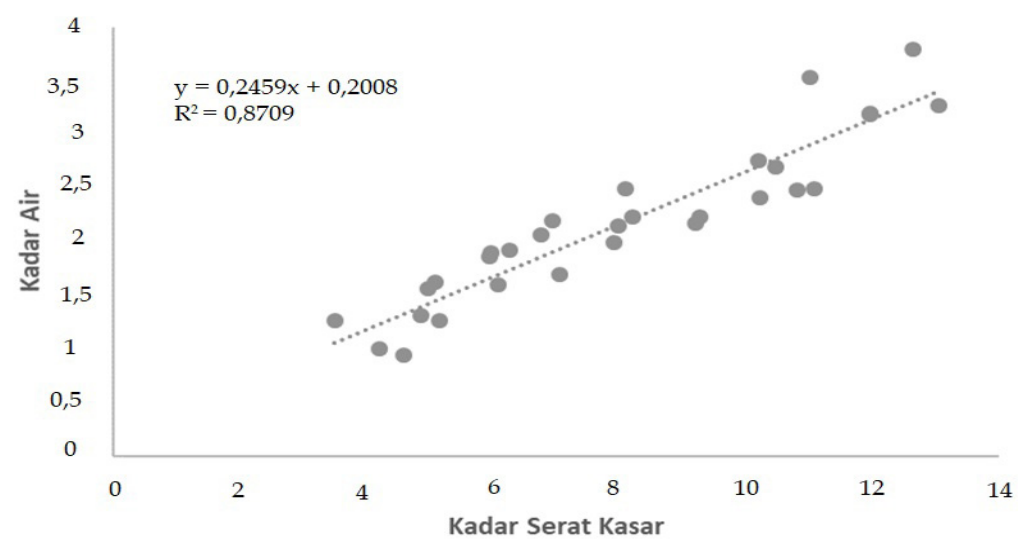

Gambar 1. Grafik korelasi kadar air dan kadar serat kasar 
serat kasar flakes, maka kadar air flakes juga semakin meningkat. Menurut Widyatmoko (2012), sebesar $14,9 \%$ dari total serat kasar yang ada pada ampas kelapa merupakan selulosa. Menurut Galanakis, (2019), struktur selulosa yang berserat (fibrious) membuatnya memiliki kemampuan yang cukup tinggi untuk menyerap air.

\section{Kadar Protein}

Kadar protein flakes berkisar antara $6,30 \%$ hingga $7,37 \%$. Perbedaan proporsi tepung ampas kelapa dan tepung beras memberikan pengaruh nyata $(a=0,05)$ terhadap kadar protein flakes. Kadar protein flakes cenderung meningkat seiring dengan berkurangnya proporsi tepung ampas kelapa dan bertambahnya proporsi tepung beras yang digunakan. Peningkatan kadar protein flakes seiring dengan berkurangnya proporsi tepung ampas kelapa dan bertambahnya proporsi tepung beras disebabkan karena kadar protein pada tepung ampas kelapa lebih rendah dibandingkan dengan tepung beras, dimana kadar protein tepung ampas kelapa sebesar $3,75 \pm 0,13 \%$ dan kadar protein tepung beras sebesar 5,95\% (USDA, 2019).

\section{Kadar Lemak}

Kadar lemak flakes berkisar antara $12,60 \%$ hingga $25,29 \%$. Perbedaan proporsi tepung ampas kelapa dan tepung beras memberikan pengaruh nyata $(a=0,05)$ terhadap kadar lemak flakes. Kadar lemak flakes cenderung menurun seiring dengan berkurangnya proporsi tepung ampas kelapa dan bertambahnya proporsi tepung beras yang digunakan. Penurunan kadar lemak flakes seiring dengan berkurangnya proporsi tepung ampas kelapa dan bertambahnya proporsi tepung beras disebabkan karena kadar lemak pada tepung ampas kelapa lebih tinggi dibandingkan dengan tepung beras, dimana kadar lemak tepung ampas kelapa sebesar 34,42 $\pm 0,92 \%$ (Tabel 4) dan kadar protein tepung beras sebesar 1,42\% (USDA, 2019).

\section{Karakteristik Fisik Flakes}

Karakteristik fisik flakes yang meliputi daya patah dan tingkat rehidrasi dapat dilihat pada Tabel 3 dan Gambar 2.

\section{Daya Patah}

Daya patah merupakan parameter pengukuran dalam bidang pangan yang digunakan untuk menggambarkan kemampuan

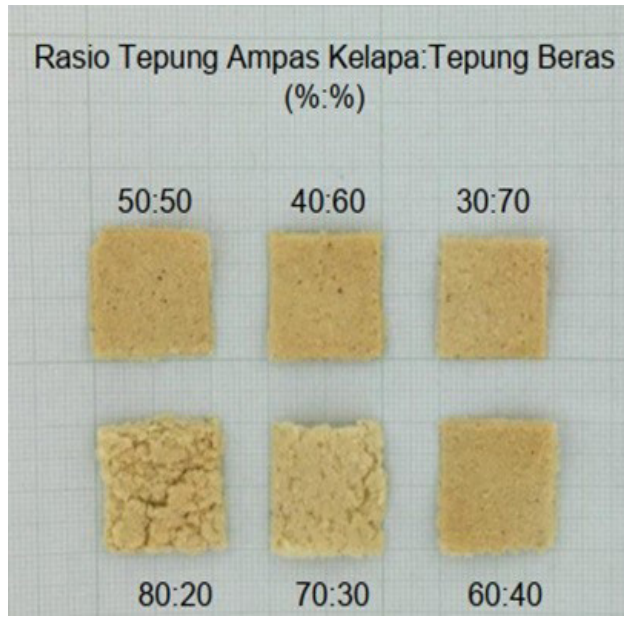

Gambar 2. Perbedaan kenampakan flakes berbagai formulasi

suatu bahan pangan menerima tekanan hingga menjadi patah ataupun hancur. Semakin sulit suatu bahan pangan hancur, maka tekanan yang dibutuhkan akan semakin tinggi.

Pengukuran ini pada umumnya dilakukan pada bahan pangan dalam bentuk padat (Bourne, 2002). Daya patah flakes berbasis tepung ampas kelapa dan tepung beras

Tabel 3. Rerata daya patah dan tingkat rehidrasi flakes

\begin{tabular}{ccc}
\hline $\begin{array}{c}\text { Proporsi Tepung Ampas Kelapa: } \\
\text { Tepung Beras (\%:\%) }\end{array}$ & $\begin{array}{c}\text { Daya Patah } \\
(\mathrm{N})\end{array}$ & $\begin{array}{c}\text { Tingkat Rehidrasi dalam } \\
\text { Media Saji (\%) }\end{array}$ \\
\hline $80: 20$ & $0,14 \pm 0,05^{\mathrm{e}}$ & $61,67 \pm 0,98^{\mathrm{a}}$ \\
\hline $70: 30$ & $0,64 \pm 0,09^{\mathrm{d}}$ & $58,15 \pm 1,24^{\mathrm{b}}$ \\
\hline $60: 40$ & $0,90 \pm 0,07^{\mathrm{d}}$ & $51,53 \pm 0,57^{\mathrm{c}}$ \\
\hline $50: 50$ & $1,58 \pm 0,13^{\mathrm{c}}$ & $47,90 \pm 0,97^{\mathrm{d}}$ \\
\hline $40: 60$ & $2,38 \pm 0,23^{\mathrm{b}}$ & $41,45 \pm 1,51^{\mathrm{e}}$ \\
\hline $30: 70$ & $3,62 \pm 0,39^{\mathrm{a}}$ & $36,70 \pm 1,79^{\mathrm{f}}$ \\
\hline
\end{tabular}

Keterangan: data yang ditampilkan adalah rerata dari 5 kali ulangan \pm standar deviasi; angka yang di dampingi notasi berbeda menunjukkan perbedaan nyata $(\alpha=0,05)$ 
berbagai perlakuan berkisar antara $0,14 \mathrm{~N}$ hingga 3,62 N. Perbedaan proporsi tepung ampas kelapa dan tepung beras memberikan pengaruh nyata $(\alpha=0,05)$ terhadap daya patah flakes. Daya patah flakes cenderung meningkat seiring dengan berkurangnya proporsi tepung ampas kelapa dan bertambahnya proporsi tepung beras yang digunakan. Peningkatan daya patah flakes seiring dengan berkurangnya proporsi tepung ampas kelapa dan bertambahnya proporsi tepung beras dipengaruhi oleh perbedaan karakteristik bahan baku. Tepung ampas kelapa yang digunakan memiliki ukuran partikel yang lebih kasar dibandingkan dengan tepung beras, sehingga penggunaan tepung ampas kelapa yang lebih banyak akan menghasilkan adonan yang kurang homogen dan produk akhir yang mudah patah (Preuss, 2020). Daya patah juga ditentukan oleh komposisi komponen penyusunnya, dimana salah satunya adalah serat kasar. Hubungan antara daya patah dengan kadar serat kasar flakes dapat dilihat pada Gambar 3. Kadar serat kasar flakes menentukan daya patah flakes sebesar $83,13 \%$. Berdasarkan hasil analisa korelasi

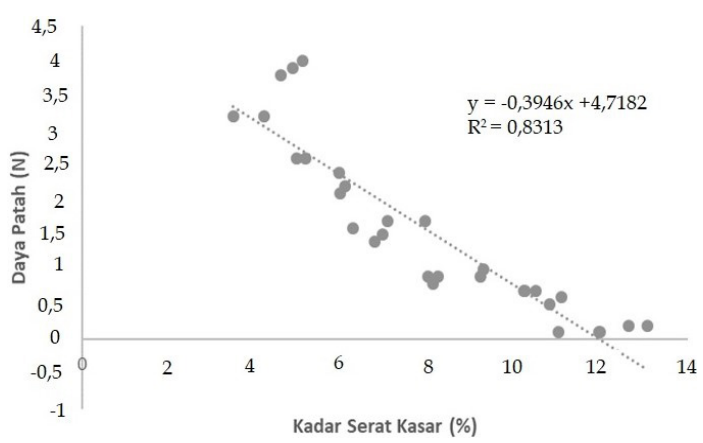

Gambar 3. Grafik korelasi daya patah dan kadar serat kasar
Pearson didapatkan nilai signifikansi sebesar 0,000 dengan koefisien korelasi sebesar -0,912 yang menunjukkan adanya korelasi yang tinggi dengan arah korelasi negatif dimana semakin rendah kadar serat kasar flakes, maka daya patah flakes akan semakin meningkat. Menurut Preuss (2020), serat pada tepung ampas kelapa tidak dapat terdispersi dengan baik ke dalam adonan flakes. Hal ini akan menghasilkan flakes yang bersifat rapuh dan mudah hancur (brittle).

Selain dipengaruhi oleh kadar serat kasar, daya patah flakes juga dipengaruhi oleh kadar protein flakes. Hubungan antara daya patah dan kadar protein flakes dapat dilihat pada Gambar 4. Kadar protein flakes menentukan daya patah flakes sebesar 66,42\%. Analisa korelasi Pearson menghasilkan nilai signifikansi sebesar 0,000 dengan koefisien korelasi sebesar 0,815 yang menunjukkan adanya korelasi yang tinggi antara daya patah dengan kadar protein flakes dengan nilai positif dimana semakin tinggi kadar protein flakes, maka daya patah flakes juga semakin meningkat. Menurut Provost et al. (2016), hal ini disebabkan karena terjadinya

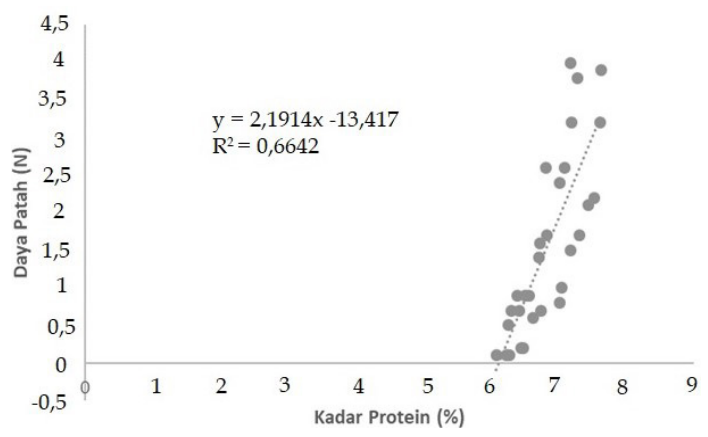

Gambar 4. Grafik korelasi daya patah dan kadar protein

Tabel 4. Karakteristik fisik dan kimia flakes perlakuan terbaik

\begin{tabular}{lc}
\hline Parameter & Flakes Perlakuan Terbaik \\
\hline Daya Patah $(\mathrm{N})$ & $0,14 \pm 0,05$ \\
\hline Tingkat Rehidrasi dalam Media Saji $(\%)$ & $61,67 \pm 0,98$ \\
\hline Kadar Air $(\%)$ & $3,4 \pm 0,26$ \\
\hline Kadar Serat Kasar (\%) & $12,12 \pm 0,78$ \\
\hline Kadar Protein $(\%)$ & $6,30 \pm 0,16$ \\
\hline Kadar Lemak $(\%)$ & $25,29 \pm 1,20$ \\
\hline Kadar Abu $(\%)$ & $1,95 \pm 0,18$ \\
\hline Kadar Karbohidrat by difference (\%) & $63,06 \pm 1,11$
\end{tabular}

Keterangan: Setiap data hasil analisa merupakan rerata dari 5 ulangan \pm standar deviasi; kadar abu flakes dihitung berdasarkan perkiraan dari kadar abu masing-masing bahan 
proses denaturasi protein. Tingginya suhu pemanggangan menghasilkan energi yang akan merusak ikatan hidrogen pada protein sehingga struktur protein berubah menjadi terbuka. Kondisi ini membuat molekul hidrofilik pada protein akan mengikat molekul air, sedangkan molekul hidrofobik akan saling berikatan dengan molekul hidrofobik dari protein lainnya. Ikatan antar protein yang terbentuk akan menghasilkan struktur yang lebih kuat dan berpengaruh terhadap kekerasan atau daya patah flakes.

\section{Tingkat Rehidrasi}

Tingkat rehidrasi flakes berkisar antara $36,70 \%$ hingga $61,67 \%$. Perbedaan proporsi tepung ampas kelapa dan tepung beras memberikan pengaruh nyata $(\alpha=0,05)$ terhadap daya patah flakes. Tingkat rehidrasi dalam media saji flakes cenderung menurun seiring dengan berkurangnya proporsi tepung ampas kelapa dan bertambahnya proporsi tepung beras yang digunakan. Peningkatan tingkat rehidrasi flakes seiring dengan berkurangnya proporsi tepung ampas kelapa dan bertambahnya proporsi tepung beras dapat terjadi karena adanya perbedaan karakteristik dari bahan baku utama yang digunakan. Tepung ampas kelapa memiliki komponen penyusun utama berupa serat yang akan membuatnya lebih mudah menyerap cairan, sedangkan kandungan pati pada tepung beras akan menghasilkan flakes dengan permukaan yang lebih rapat sehingga penyerapan cairan akan terjadi lebih lambat (Bhattacharya, 2015). Hubungan antara tingkat rehidrasi dengan kadar serat kasar flakes dapat dilihat pada Gambar 5.

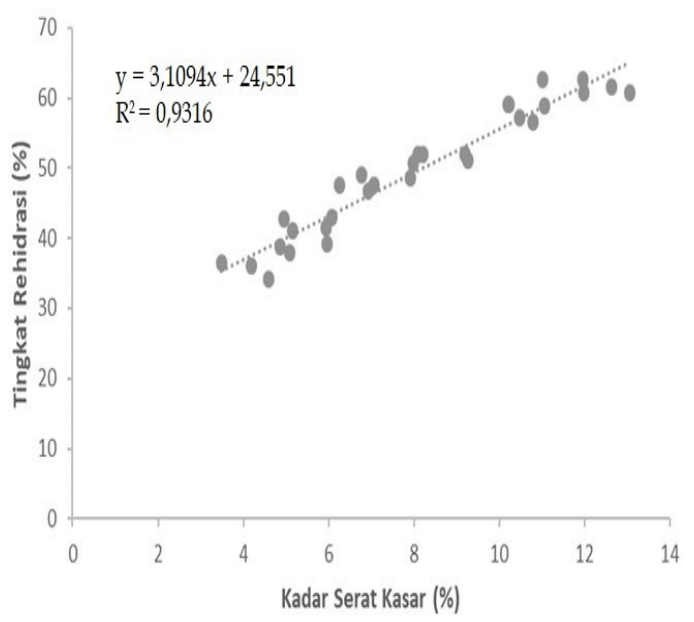

Gambar 5. Grafik korelasi tingkat rehidrasi dan kadar serat kasar

\section{Penentuan Flakes Perlakuan Terbaik}

Flakes perlakuan terbaik ditentukan berdasarkan karakteristik fisik yang meliputi daya patah dan tingkat rehidrasi dalam media saji, serta karakteristik kimia yang meliputi kadar air, kadar serat kasar, kadar protein, dan kadar lemak. Parameter fisik flakes perlakuan terbaik ditentukan berdasarkan preferensi subjektif, sedangkan kriteria parameter kimia ditentukan berdasarkan SNI 2973:2011. Flakes perlakuan terbaik yang didapatkan adalah flakes yang dibuat dengan proporsi tepung ampas kelapa:tepung beras sebesar 80\%:20\%. Karakteristik fisik dan kimia flakes perlakuan terbaik dapat dilihat pada Tabel 4.

\section{Informasi Nilai Gizi Flakes Perlakuan Terbaik}

Perhitungan nilai gizi flakes perlakuan terbaik mengacu pada Peraturan Kepala Badan Pengawas Obat dan Makanan Republik Indonesia Nomor 22 Tahun 2019. Persentase Angka Kecukupan Gizi (AKG) dihitung berdasarkan nilai Acuan Label Gizi (ALG) kelompok umum yang terdapat dalam Peraturan Kepala Badan Pengawas Obat dan Makanan Republik Indonesia Nomor 9 Tahun 2016. Satu takaran saji (30 g) flakes perlakuan terbaik memiliki energi total sebesar 150 Kkal dengan nilai gizi berupa lemak total sebesar $8 \mathrm{~g}$, protein sebesar $2 \mathrm{~g}$, karbohidrat total sebesar $19 \mathrm{~g}$, dan serat pangan tidak larut sebesar $4 \mathrm{~g}$. Persentase AKG flakes perlakuan terbaik adalah $11 \%$ lemak total, $3 \%$ protein, $6 \%$ karbohidrat total, dan $12 \%$ serat pangan tidak larut.

\section{Klaim Gizi Pangan Flakes Perlakuan Terbaik}

Flakes perlakuan terbaik mengandung serat kasar sebanyak 12,12 g per 100 atau $4 \mathrm{~g}$ per takaran saji. Berdasarkan kadar seratnya, flakes perlakuan terbaik ini telah memenuhi salah satu persyaratan klaim kandungan zat gizi sebagai produk pangan Tinggi Serat menurut Peraturan Kepala Badan Pengawas Obat dan Makanan Republik Indonesia Nomor 13 Tahun 2016, yaitu minimal kandungan serat sebesar $6 \mathrm{~g}$ dalam $100 \mathrm{~g}$. Flakes perlakuan terbaik kemudian dibandingkan dengan dua produk flakes komersial yang dapat dilihat pada Tabel 5 .

Persyaratan lain yang perlu terpenuhi untuk pencantuman klaim gizi pangan olahan tercantum pada ayat (1) Pasal 6, yaitu persyaratan asupan per saji tidak lebih dari 
Jurnal Teknologi Pertanian Vol. 21 No. 3 [Desember 2020] 155-164 Pemanfaatan Tepung Ampas Kelapa dalam Pembuatan Flakes Cereal [Murtini dkk]

Tabel 5. Perbandingan nilai gizi flakes perlakuan terbaik dan flakes komersial per takaran saji

\begin{tabular}{lccc}
\hline Parameter & $\begin{array}{c}\text { Flakes Perlakuan Terbaik } \\
(30 \mathrm{~g})\end{array}$ & $\begin{array}{c}\text { Flakes Komersial 1 } \\
(30 \mathrm{~g})\end{array}$ & $\begin{array}{c}\text { Flakes Komersial } 2 \\
(35 \mathrm{~g})\end{array}$ \\
\hline Energi $(\mathrm{Kkal})$ & 150 & 110 & 140 \\
\hline Lemak Total $(\mathrm{g})$ & 8 & 0,5 & 3,5 \\
\hline Karbohidrat $(\mathrm{g})$ & 19 & 24 & 24 \\
\hline Serat $(\mathrm{g})$ & 4 & 1 & 3 \\
\hline Protein $(\mathrm{g})$ & 2 & 2 & 5 \\
\hline
\end{tabular}

$18 \mathrm{~g}$ total lemak, $4 \mathrm{~g}$ lemak jenuh, $60 \mathrm{mg}$ kolestrol, dan $300 \mathrm{mg}$ natrium. Berdasarkan persyaratan tersebut, kandungan lemak total flakes perlakuan terbaik telah terpenuhi yaitu sebesar $8 \mathrm{~g}$ per takaran saji. Namun, perlu dilakukan penelitian lebih lanjut untuk mengetahui kandungan lemak jenuh, kolestrol, dan natrium flakes perlakuan terbaik agar klaim gizi dapat ditentukan.

\section{SIMPULAN}

Perlakuan perbedaan proporsi tepung ampas kelapa:tepung beras pada pembuatan flakes cereal memberikan pengaruh nyata terhadap karakteristik fisik dan kimia flakes yang meliputi daya patah, tingkat rehidrasi dalam media saji, kadar air, kadar serat kasar, kadar protein, dan kadar lemak. Flakes perlakuan terbaik yang didapatkan adalah flakes yang terbuat dari $80 \%$ tepung ampas kelapa dan $20 \%$ tepung beras dengan nilai daya patah sebesar $0,14 \pm 0,05 \mathrm{~N}$, tingkat rehidrasi dalam media saji sebesar $61,67 \pm 0,98 \%$, kadar air sebesar 3,4 $40,26 \%$, kadar serat kasar sebesar 12,12 $\pm 0,78 \%$, kadar protein sebesar 6,30 $\pm 0,16 \%$, kadar lemak sebesar $25,29 \pm 1,20 \%$, kadar abu sebesar 1,95 $\pm 0,18 \%$, dan kadar karbohidrat sebesar 63,06 $\pm 1,11 \%$. Satu takaran saji flakes perlakuan terbaik memiliki energi total sebesar $150 \mathrm{Kkal}$.

\section{DAFTAR PUSTAKA}

AOAC. 1990. Official Methods of Analysis of The Association of Analytical Chemist. Washington DC. Benyamin Franklin Station

AOAC. 1995. Official Methods of Analysis of The Association of Analytical Chemist. Washington DC. Benyamin Franklin Station
AOAC. 2000. Official Methods of Analysis of The Association of Analytical Chemist. Washington DC. Benyamin Franklin Station

AOAC. 2005. Official Methods of Analysis of The Association of Analytical Chemist. Washington DC. Benyamin Franklin Station

BeMiller, JN., Whistler, RL. 2009. Starch: Chemistry and Technology. Academic Press. Amsterdam

Bhattacharya, S. 2015. Conventional and Advanced food processing Technologies. John Wiley \& Sons. Chichester

Bourne, M. 2002. Food Texture and Viscosity: Concept and Measurement. Academic Press. New York City

BPOM. 2016. Peraturan Kepala Badan Pengawas Obat dan Makanan Republik Indonesia Nomor 9 Tahun 2016 Tentang Acuan Label Gizi. BPOM. Jakarta

BPOM. 2016. Peraturan Kepala Badan Pengawas Obat dan Makanan Republik Indonesia Nomor 13 Tahun 2016 Tentang Pengawasan Klaim Pada label dan Iklan Pangan Olahan. BPOM. Jakarta

BPOM. 2019. Peraturan Kepala Badan Pengawas Obat dan Makanan Republik Indonesia Nomor 22 Tahun 2019 Tentang Informasi Nilai Gizi Pada Label Pangan Olahan. BPOM. Jakarta

BSN. 1992. Cara Uji Makanan dan Minuman. Dewan Standarisasi Nasional. Jakarta

FAOSTAT. 2020. Data Coconut Production Quantity 2018. Diakses 10 Juli 2019. <http://www.fao.org/faostat/ en/\#data/QC>

Fife, B. 2014. The Coconut Ketogenic Diet: Supercharge Your Metabolism, Revitalize Thyroid Function, and Lose Excess Weight. Piccadilly Books. Colorado Springs

Galanakis, CM. 2019. Dietary Fiber: Properties, Recovery, and Applications. Academic Press. London 
Jurnal Teknologi Pertanian Vol. 21 No. 3 [Desember 2020] 155-164

Pemanfaatan Tepung Ampas Kelapa dalam Pembuatan Flakes Cereal [Murtini dkk]

Hafiza, -S., Ahmad A, N, -G., Nor H, -B., 2012. Screening of significant media components for production of bioprotein from coconut dregs using statistical approach. International Food Research Journal. 19(2), 499-502. http://www. ifrj.upm.edu.my $/ 19 \% 20(02) \% 202012 /$ (17)IFRJ-2012\%20Hafiza.pdf

Hosseini, S. M., Soltanizadeh, N., Mirmoghtadaee, P., Banavand, P., Mirmoghtadaie, L., Shojaee-Aliabadi, S. 2018. Gluten-free products in celiac disease: Nutritional and technological challenges and solutions. Journal of Research in Medical Sciences: The Official Journal of Isfahan University of Medical Sciences. 23, 109. https://doi. org/10.4103/jrms.JRMS_666_18

Imanningsih, -N., 2012. Profil gelatinisasi beberapa formulasi tepung-tepungan untuk pendugaan sifat pemasakan. Jurnal Penelitian Gizi dan Makanan. 35(1), 13-22. http:// ejournal.litbang.kemkes.go.id/ index.php/pgm/article/view/3079

Maskan, M. 2012. Advances in Food Extrusion Technology. CRC Press. Boca Raton

Preuss, HG., Bagchi, D. 2020. Dietary Sugar, Salt and Fat in Human Health. Academic Press. London

Provost, JJ., Colabroy, KL, Kelly, BS, Wallert, MA. 2016. The Science of Cooking: Understanding the Biology and Chemistry Behind Food and Cooking. John Wiley \& Sons. Hoboken

Ramaswamy, -L., 2014. Coconut flour - A low carbohydrate, gluten free flour: A review article. International Journal of Ayurvedic and Herbal Medicine. 4(1), 1426-1436. http://interscience.org. uk/v4-i1/1\%20ijahm.pdf

Ranganna, S. 1977. Manual Analysis of Food and Product. McGraw Hill Co. New Delhi
Sereewat, -P., Suthipinittham, -C., Sumathaluk, -S., Puttanlek, -C., Uttapap, -D., Rungsardthong, -V., 2015. Cooking properties and sensory acceptability of spaghetti made from rice flour and defatted soy flour. LWT-Food Science and Technology. 60(2), 1-7. https://doi. org/10.1016/j.lwt.2014.10.001

USDA. 2019. Rice Flour, White, Unenriched (SR Legacy, 169714). U.S. Department of Agricultural

Widyatmoko, -H., Sawitri, A, -D., 2012. Pembuatan etanol dari limbah ampas kelapa dengan menggunakan rhizopus oligosporus dan saccharomyces cerevisiae dengan penambahan phospat. Indonesian Journal of Urban and Environmental Technology. 6(1), 15-22. http:// dx.doi.org/10.25105/urbanenvirotech.v6i1.699

Yalegama, L, L, W, -C., Karunaratne, D, -N., Sivakanesan, -R., Jayasekara, -C., 2013. Chemical and functional properties of fibre concentrates obtained from by-products of coconut kernel. Food Chemistry. 141(1), 124-130. https:/ / doi. org/10.1016/j.foodchem.2013.02.118

Yuwono, S., Susanto T. 1998. Pengujian Fisik pangan. Jurusan Teknologi Hasil Pertanian, Universitas Brawijaya, Malang

Zhou, W., Hui, YH., Lyn, ID., Pagani, MA., Rosell, CM., Selman, JD., Therdthai, N. 2014. Bakery Products Science and Technology, Second Edition. John Wiley \& Sons. Hoboken

Zhu, -X., Zhao, -Z., Wang, -L., Zhang, -L., 2014. A new method to measure fat content in coconut milk based on Ytype optic fiber system. Optik. 125(20), 6172-6178. https://doi.org/10.1016/j. ijleo.2014.06.115 